\title{
Cavafy and His Heirs in America
}

Among early 2oth century poets on the far side of the Atlantic who require translation into English, the Alexandrian Greek poet C.P. Cavafy is now one of the major figures that an American poet is likely to consider essential reading at some point, if not today, than maybe next month or maybe next summer, someday soon. But if this statement is true, it is only fairly recently true. Though Cavafy, who was born in 1863 and died in 1933, had his devotees in England well before and during the Second World War-E.M. Forster, T.E. Lawrence, and Arnold Toynbee, among others-and though John Mavrogordato's translation of his poems appeared in the United States in 1952, it was not until the next decade that American readers of poetry began to take an interest in the Alexandrian's work in significant numbers.

The first source of this growing interest was the publication in 1961 of the American edition of Lawrence Durrell's The Alexandria Quartet in which Cavafy appeared as "the Poet of the city" and "the old man," in both instances identified by the novelist in an endnote and celebrated by Durrell's free translations of Cavafy's "The City" and "The God Abandons Antony" in the "Consequential Data" addendum to the first novel of the quartet, Justine. Durrell's work became an immediate and enduring best-seller in the United States, as it previously had been in England, and Cavafy's reputation began to prosper to a degree as a consequence.

But the principal source of his increasingly central standing in the minds of American poets was surely the introduction that W.H. Auden provided for the 1961 publication of Rae Dalven's English translation of Cavafy's poems. Auden, then living in the United States and the dean of poets for many younger American writers, revealed, at the start of his commentary, that for over thirty years Cavafy had "remained an influence on my own writing; that is to say, I can think of poems which, if Cavafy were unknown to me, I should have written quite differently or perhaps not written at all." And he added that this influence was exercised not by way of Modern Greek, which he did not know, but by way of English and 
French translations. This suggested to him that though he had "always believed the essential difference between prose and poetry to be that prose can be translated into another tongue but poetry cannot," he now had to acknowledge that "there must be some elements in poetry which are separable from their original verbal expression and some which are inseparable." In the case of Cavafy, he finds that what survives translation, any translation (presumably including the Rae Dalven version he is introducing) is Cavafy's "unique perspective on the world" and "unique tone of voice." Let me add a personal note here: when Auden visited Princeton back in the late 196os, I had a chance to ask him if I was right in thinking that his "Atlantis" was a poem he might have written differently had he not known Cavafy. His answer, to my mind only half in jest: "If I'd known Cavafy would become as famous as he's becoming, I wouldn't have published that poem at all."

Auden's 1961 revelations, in the same year that Durrell's The Alexandria Quartet crossed into the American literary landscape, surely led poets on this side of the Atlantic who considered Auden their mentor to look more closely into a Greek poet then known only by the few who happened to have come across Mavrogordato's 1952 translation or who had been introduced to his work by the occasional translations appearing in literary quarterlies. And, as is indicated by the dates of composition of some of the poems by American poets that I'm reviewing here, during the two decades following Auden's 1961 remarks, several of the best poets of the postwar generation publishing in America offered poems that were modeled after Cavafy, Alan Dugan, James Merrill, and Daryl Hine the earliest of these.

But it took at least another decade for Cavafy to become established in the United States as a major foreign poet of the twentieth century, the kind of voice that any aspiring poet ought to listen to with serious-if not somber-attention, even in translation. A new collected edition of his work in English appeared in 1975, the socalled Keeley-Sherrard version, along with several critical monographs, and during the 1980 os the discussion of his work broadened measurably among both critics and general readers of poetry interested in the work of the best foreign writers. Then an event occurred in May 1994 that made Cavafy a sudden, if relatively brief, best-seller among poets: the last of Jacqueline Kennedy-Oanassis's 
companions, Maurice Tempelsman, read a translation of Cavafy's "Ithaka" at her funeral on the 23rd of that month, adding lines of his own at the end that gave the poem a directly personal relevance. Since "Ithaka" - brought up again and again to signal the joys of travel or the road ahead after graduation ceremonies-remains perhaps the best known of Cavafy's poems after "Waiting for the Barbarians," I won't quote the poem here but simply offer Mr. Templesman's addendum to record his parting gesture toward one of Cavafy's ardent readers in this country: "And now the journey is over, too short, alas too short. / It was filled with adventure and wisdom, laughter and love, gallantry and grace. / So farewell, farewell."

In reporting the funeral, and after a bit of transatlantic research that included a phone call to me at ouzo hour while I was visiting friends in Salonika, Greece, The New York Times decided to publish the full text of Cavafy's poem in the Princeton University Press version, and as a consequence, in the weeks following the funeral, the Alexandrian's Collected Poems sold some hundreds and hundreds of copies, almost doubling the sales of twenty years in as many days. Then sales returned to the slow poetic rhythm of relatively silent feet so familiar to foreign poets and their translators, though Cavafy has again been resurrected in this context by the inclusion of "Ithaka" in the volume of Jacqueline Kennedy-Onassis's favorite poems gathered by her daughter Caroline (this time in Rae Dalven's version, entitled "Ithaca," rather than in the version that appeared in The New York Times.)

When Auden suggested to the reader of his commentary that Cavafy led him to write certain poems "differently" than he might have without Cavafy's guidance, he provides me with a theme for these remarks. The way one writes "differently" because of Cavafy's presence as the guiding spirit of a poem can serve as the defining mode of the poems by several of the American poets that I will be quoting here. And when Auden speaks of the Alexandrian's "unique perspective on the world" and his "unique tone of voice," he seems to me to identify the essential inherited qualities, even received by way of translation, which characterize most of the poems that American poets have chosen to designate, either by title or epigraph or the phrase "after Cavafy," as offerings in the mode of their Alexandrian predecessor. Recently a Greek poet and critic named 
Nasos Veyanas decided to collect as many poems as he could by European, Latin American, and Anglo-American poets that indicated a stated affinity to Cavafy either by attribution or title or quotation in a poem's text, and he ended up with contributions from 29 countries. The American section, which I helped him select, included thirteen poets, and that was merely a partial representation. I won't have space to introduce all of these, but I'll try to provide a sample that focuses on two of the principal preoccupations that appear in Cavafy's mature work, what he himself called "the erotic" and "the historical." And as he also pointed out, those two categories often merge.

I begin with the Cavafian perspective on what one might call the "divinity" of unconventional love, whether specifically identified as gay or simply as grandly sensual, intoxicating, orgiastic, debauched, as in the poem "One of Their Gods," where those who reside in the August Celestial Mansions cannot resist coming down to earth to share certain of the fleshly pleasures available in the world of mortals:

When one of them moved through the marketplace of Selefkia just as it was getting dark-

moved like a young man, tall, extremely handsome, with the joy of being immortal in his eyes, with his black and perfumed hairthe people going by would gaze at him, and one would ask the other if he knew him, if he was a Greek from Syria, or a stranger. But some who looked more carefully would understand and step aside; and as he disappeared under the arcades, among the shadows and the evening lights, going toward the quarter that lives only at night, with orgies and debauchery, with every kind of intoxication and desire, they would wonder which of Them it could be, and for what suspicious pleasure he had come down into the streets of Selefkia from the August Celestial Mansions. 
James Merrill was among the very first American poets to recognize Cavafy's genius, to comment perceptively on his work, and even on occasion to translate him. And though Merrill's own voice is generally more elaborate, stylistically playful, and technically intricate than Cavafy's, some of his very best erotic poems clearly demonstrate that they have learned from the Cavafian perspective. In his "Days of 1964," the title echoing a number of the titles of Cavafy poems that celebrated love in an advanced Alexandrian mode half a century earlier, we find the speaker setting his poem on Lycabettus hill in Athens, which he climbs often to bring wild flowers home to his lover and, on one occasion, a strange tale of finding their cleaning lady, Kyria Kleo transformed into a mysterious goddess of love. This is a woman the speaker has earlier described as fat, past fifty, like "a Palmyra matron / Copied in lard and horsehair" who sighs the day long with pain from her hurting legs or with love for so much of what is around her-including him, his lover, the bird, the cat-that the speaker thinks "she was love." But on this particular day, when he sees her by chance trudging into the pine forest on Lycabettus hill, her face appears to him suddenly painted "Clownwhite, white of the moon by daylight, / Lidded with pearl, mouth of a poinsettia leaf, / Eat me, pay me," what he takes to be "the erotic mask / worn the world over by illusion / To weddings of itself and simple need." But I'll let the rest of the poem speak for itself:

Startled mute, we had stared-was love illusion?-

And gone our ways. Next, I was crossing a square

In which a moveable outdoor market's

Vegetables, chickens, pottery kept materializing

Through a dream-press of hagglers each at heart

Leery lest he be taken, plucked,

The bird, the flower of that November mildness,

Self lost up soft clay paths, or found, foothold,

Where the bud throbs awake

The better to be nipped, self on its knees in mud-

Here I stopped cold, for both our sakes; 
And calmer on my way home bought us fruit.

Forgive me if you read this. (And may Kyria Kleo, Should someone ever put it into Greek And read it aloud to her, forgive me, too.) I had gone so long without loving I hardly knew what I was thinking.

Where I hid my face, your touch, quick, merciful, Blindfolded me. A god breathed from my lips. If that was illusion, I wanted it to last long; To dwell, for its daily pittance, with us there, Cleaning and watering, sighing with love or pain.

I hoped it would climb when it needed to the heights

Even of degradation, as I for one

Seemed, those days, to be always climbing

Into a world of wild

Flowers, feasting, tears-or was I falling, legs

Buckling, heights, depths,

Into a pool of each night's rain?

But you were everywhere beside me, masked,

As who was not, in laughter, pain, and love.

In yet another Cavafian mode, one that treats erotic frustration, illusion, and even loss with irony, we find an early poem by Daryl Hine called "What's His Face: after Cavafy." Again, the voice is Hine's own, and the wit a touch more flamboyant than what we normally find in the Alexandrian, but in this evocation of a "zoomorphic" and "ithyphallic" god, there is enough of the Cavafian perspective, if not the tone, to justify the poet's signal of adaptation in the title:

The god that is leaving me-perhaps has left

Already (relieved of his presence, I feel sorry) -

What was his name? Apollo, Eros, Zeus,

As he pretends? Or one of their attendants,

By turns erotic, appalling, zoomorphic?

He must have been some merely local demon, 
His divinity unknown to the tribe next door,

His attributes demonic to a fault,

Ithyphallic, pushy, mischievous,

Wickedly undependable, adept

At deceit as he denies he led you on,

Impalpable, incomprehensible...

He appeared in the flesh, what? Half-a-dozen times?

Smiling his cryptic, unforgiving smile,

Saying little, glimpsed in intervals

Of sleep or at a distance, domestic idol

Destructive of trust and quiet. Now he's gone

Life is private again, desecrated, dull

Without his infrequent, fraudulent manifestations,

Without his unconvincing oracles.

His image, which was cast in terra cotta

And clumsily but not unattractively modeled,

Smashed, and his untidy shrine abandoned,

After giving nothing to his votary,

Has he turned his face towards the dawn?

Is he visiting with the Hyperboreans? God

Forgive me, what made me think he was a god?

Other essential aspects of Cavafy's erotic perspective are those that Louise Glück highlights in a brilliantly perceptive note that she sent me to accompany her contribution to the Vayenas volume, the poem "Marathon 3: The Encounter": eros as both solitary and acutely dependent, as "stopped time," and as fated submission. I find her commentary especially compelling because it shows us the sympathetic response of a woman to an erotic world that in one sense couldn't be farther from her own, yet a response that illustrates how successful Cavafy's poetry was-and still is-in transcending the poet's own eccentricities, transforming his idiosyncratic vision into a kind of universal poetic statement that readers can appreciate whatever their personal orientation. Here is Louise Glück's full note:

Because Cavafy was the first poet I read whose erotic poems corresponded to my own perception of erotic experience, he made a world that had been unavailable to my own art possible: a crucial gift, given my own obsessions. Most of what I had read that 
appeared to be, or was discussed as being, erotic, reported ecstasy direct from the embrace, from within the embrace: it was explicit, physical, active, and, when not brilliantly written, embarrassing. I suppose this is a description of heterosexual male fantasy, but these terms seem too simple. In any case, such art seemed remote from my own perception of experience. What I found in Cavafy affirmed an experience of eros as profoundly solitary and (simultaneously) acutely dependent. This was eros as non-dynamic: in stopped time, the dynamic has no function. Reading Cavafy for the first time (in English, I should add) I saw the infinity I knew about, an immense vista of silence between one line and the next: eros was that interval, not the action of the sentence. Or perhaps what I responded to was simply the atmosphere of fated submission. I might have found another model (but have not), and my own poems about physical love seem to me tribute to the great poet in whose debt I remain.

And here is "Marathon 3: The Encounter" that this note highlights:

You came to the side of the bed and sat staring at me.

Then you kissed me-I felt hot wax on my forehead.

I wanted it to leave a mark: that's how I knew I loved you.

Because I wanted to be burned, stamped, to have something in the endI drew the gown over my head, a red flush covered my face and shoulders. It will run its course, the course of fire, setting a cold coin on the forehead, between the eyes. You lay beside me; your hand moved over my face as though you had felt it alsoyou must have known, then, how I wanted you. We will always know that, you and I. The proof will be my body. 
We find a related theme in Edward Field's "The Lost, Dancing: After Cavafy," a poem in which drummers and dancers who are called "your fate" (see the Alexandrian's "The God Abandons Antony") arrive to show you in your moment of loss that "what you had you had, / you loved the way few men have." And again, in Joseph Stroud's "Reading Cavafy Alone in Bed," we encounter another typical Cavafian perspective: eros as the agent of memory, brought back to life in the body's recollection of another body's touch and of the room, with its flickering candles, where the past had its moment of intense pleasure.

But in what space I have left I want to focus on the unique Cavafian perspective and something of the unique tone of voice that are apparent in those American poems that speak within a historical, or pseudo-historical, context. "Waiting for the Barbarians" is the most dramatic model in this context, but I will assume the poem is familiar enough to allow me to skip quoting it and to indulge my affection for a lesser known poem, one called "Ionic," where the erotic and the historical merge to provide something more than the usual ironic commentary on the ignorance or hubris or complacency of the mighty who are unprepared to suffer the fate that awaits all things mortal. There is irony in this poem: a Christian speaker, living around $400 \mathrm{AD}$, who proclaims that the pagan gods have not died simply because his fellow Christian converts in Asia Minor Ionia have broken their statues and driven them out of their temples. From this speaker's point of view, it is in fact clear that the gods, if they ever left, have now returned as etherial presences in the hilly landscape, brought back to this region by their love for the "land of Ionia" that is carried still in memory by their souls. The representative godly presence that the Christian speaker encounters is an "ephebic" figure of the kind that most appealed to the poet's hedonistic bias, another deified image of sensuality if you will, but his arrival on the scene is in the context of the poet's celebration of landscape-a rare preoccupation in his poetry. And it is accompanied by a lyricism that would also seem to transcend the poem's irony-again, even in translation. 
That we've broken their statues,

that we've driven them out of their temples, doesn't mean at all that the gods are dead.

$\mathrm{O}$ land of Ionia, they're still in love with you, their souls still keep your memory.

When an August dawn wakes over you, your atmosphere is potent with their life, and sometimes a young etherial figure, indistinct, in rapid flight, wings across your hills.

History in Cavafy always rises to the level of metaphor, and as I've suggested elsewhere, over the course of years, his historical and pseudo-historical poems created an ongoing myth that celebrated the virtues of historical perspicacity, though of seeing things not only for what they are but for what they are likely to become, including the inevitable reversals in history that finally teach one not so much the moral as the tragic sense of life. His myth also teaches the virtues of irony about the hubris that often accompanies the game of nations, the ideology of the mighty, and as we saw in "Ionic," the victory of one religion over another. And in his version of the ironic mode, there is almost always a degree of distance between the poet's perspective and that of the characters he portrays or even the speakers he creates to narrate the events that shape his historical metaphor.

I will offer two examples of poems by American poets that pay homage to this aspect of the Alexandrian's perspective, both poems by friends of mine who are included in the Vayenas selection, along with others by Rachel Hadas, Daniel Halpern, and Linda Pastan that I'll have to pass over. The reader will immediately recognize the two poems I've chosen as being in the Cavafian historical mode, but both transform that mode imaginatively without the poets losing their characteristic personal voice. The first is a prose poem by Christopher Merrill called "Sagebrush: After Cavafy," a work that subtly captures the perennial ironies that rule the blighted land of those who wait for the barbarians at the gate, the new barbarians, anticipated by the general who lifts his fork before his starving troops, and the foot soldiers reaching for their inhalers, while maybe only the asthmatic priest and the prisoners behind the last 
barbed wire line of defense are capable of knowing the price of wisdom in their threatened wasteland. It is a poem that now, in the best Cavafian tradition, carries a certain prophetic aura:

These are the last days of its empire. No flags fly from its dead limbs, nor do its branches lost to age or blight bend in the wind. Only two outposts remain, two settlements of gray and green, in the largest house of which the general lifts his fork before casually signing marching orders for his starving troops. Here in a field of shrunken cabbages the asthmatic priest wakes in the night, gasping. Foot soldiers reach for their inhalers. Courtesans bronze their nails. In a world of whiskers and spent flowers there are always rumors of barbarians gathering beyond the barbed wire the prisoners strung across the last meadow on our maps. Even our bravest cartographer prefers the company of the general to wandering past that fence, though the general will never share his food. No doubt a messenger from the capital is already on his way to the first outpost, bearing orders for our retreat. Who will inherit the promise of these stiff limbs? Ants, grass, and wind. What is the price of wisdom here? Only the priest and prisoners can tell.

The second poem that I take to be clearly in the Alexandrian's historical mode is Carolyn Kizer's "The Oration: After Cavafy." Here we are offered an unidentified public speaker in an unidentified time who, against the wishes of a certain "savior" in his passion, turns the murderous mob around with his eloquence only to learn that the minute he is gone, the savior makes outrageous statements about being the son of God and such that get him strung up again. But in the true Cavafian mode, it is the speaker's sense of his own grand eloquence that becomes, to his mind, the enduring legacy of the pseudo-historical moment:

The boldest thing I ever did was to save a savior.

I reached heights of eloquence never achieved before

Or since. My speech turned the mob around!

They lifted the rood from his back, they dropped to the ground

Their nails and flails. But the whole time I spoke

(It's a wonder it didn't throw me off my stride)

The prophet or seer or savior, whatever you care to call him, 
Kept groaning and muttering, telling me to be silent.

He was mad of course, so I simply ignored him. Poor fellow,

The beating they had given him must have turned his wits.

Every ounce of persuasion it took to convince the crowd In the powerful sun, including the priests and his followers, Exhausted me utterly. When I was sure he was safe, The ungrateful fellow! I took my way home and collapsed On my cushions with chilled wine. Then, I heard later, The savior harangued the mob with outrageous statements That roused them to fury anew: he denounced the priesthood As corrupt; he pronounced himself king of the world;

He said God was his father. So they strung him up again.

A violent thunderstorm woke me to a sky full of lightning

So I rushed out in the rain, forgetting my cloak,

And found him dead and alone except for a handful of women Weeping and carrying on. Well, it taught me a lesson,

To mind my own business-Why, the crowd might have turned on me!

Still, I have to be proud of my eloquence.

It was the speech of my life.

Carolyn Kizer's poem was included in The Best American Poetry 2000, and in that volume she provides us with an illuminating note on the poem that seems to me a valuable addendum to the theme I've been exploring. I quote it here in part:

My friend, Edmund ("Mike") Keeley... told me he was collecting poems by American poets who had been influenced by Constantine Cavafy. I had always cared deeply for Cavafy, but I had never modeled a poem on him. So now I did. My first effort was a close imitation, called "Days of 1986" (a number of poets have used variants on this particular poem's title and content). But on thinking about it, I realized that one of [Cavafy's'] most characteristic innovations was to write about an important historical or mythical event or person from the standpoint of an insignificant person, a bystander, "an attendant lord." So that was the usage I adopted in writing "The Oration." When I wrote that the poem 
was "after Cavafy" I was rather shocked when the editor of Threepenny Review, who conditionally accepted the poem, inquired if "after Cavafy" meant that it was a translation! I replied that "after" meant "in the style of." I had thought that every literary person accepted that. Anyway, she printed it. Another remarkable thing about Cavafy's poems is the absence of specific metaphors. There is an overriding metaphor in most of the poems: the comparison of what was with what is. I've always been drenched in metaphor-although wary of the word "like." So now, having immersed myself in Cavafy yet again, I shall try to be stingy with metaphors.

As we have seen, Carolyn Kizer's adaptation is appropriately stingy with specific metaphors, but what her note underlines elsewhere is also demonstrated by her poem: first, the advantage for irony, especially dramatic irony, of seeing the historical moment from an outsider's limited point of view not shared by the poet or the perceptive reader, and second, the crucial presence of an overriding metaphor that not only puts the specific historical moment, what was, into what is, but, as the finest overriding metaphors have a way of doing, into the realm of perennial truth: what will remain.

I want to conclude these remarks by pointing to a bit of literary history that some may see as another instance of Cavafian irony. As far as I know, each of the American poets I've quoted here came to the Alexandrian poet as Auden did, by way of translation. And one or another of the translations they encountered-whether in Mavrogordato's early version as in the case of James Merrill, or Rae Dalven's later version, or that of the selection in Six Poets of Modern Greece published in the same year, or other versions down the road-eventually inspired our American poets to attempt an adaptation or, more precisely, a transformation, that is, a creative act "after" the translated poet or "in the style" of the translated poet which at the same time became a personal evocation in the poet's particular voice. And these creative acts in turn inspired a Greek poet, Nasos Vayenas, to collect the work of Cavafy's American heirs for publication in Greece. Here is what some might take to be the Cavafian irony: publication of these transformations not in the original English but in translations into Greek. So what we have at this moment in the Alexandrian's legacy is a celebration of his Greek 
poems that were translated into English and that subsequently inspired transformations into English which have now been translated into Greek. But I don't find irony in this so much as a further affirmation that translation-yes, even translation of poetry, despite Robert Frost's famous dismissal-continues to be an essential bridge between different literatures. It can also be an enduring source of inspiration for those practitioners of the art who have discovered, as Auden finally did (and I quote him), that "it is possible to be poetically influenced by work which one can read only in translation," and, as I hope we have seen, to be influenced in ways that, in the best of our poets and the best of their sources, serve so well both to teach and to delight. 